\title{
Fundamental Factors and Islamic Stock Returns of Food and Beverage Companies in Indonesia
}

\author{
Siti Amaroh*, Siti Mudrikatuz Zahro², Masturin ${ }^{3}$ \\ ${ }^{1,2,3}$ Islamic Economic Department, IAIN Kudus, Indonesia.
}

Submitted: 9 January 2020, Accepted: 11 June 2020, Published: 12 June 2020

\begin{abstract}
This study examines the influence of issuers' fundamental factors on Islamic stock returns in Indonesia. It is documentary research with data from company financial reports in the food and beverage industry. The companies were listed on the Indonesia Sharia Stock Index during 2015-2019. The sample selection was based on purposive sampling. The selected companies continuously published financial statements and had no negative earning per share. Based on the inclusion criteria, nine consistent firms were entered in data processing by Eviews software through several stages. The first stage involved determining the panel data regression model with common, fixed, and random effect models. The second stage was the selection of the fit model using 3 tests, including Chow, Lagrangian Multiplier, and Classic Assumption. The common effect was the fit panel data regression model. The results show that Return on Assets positively influences Islamic stock returns. However, Debt to Equity Ratio and Earning per Share do not affect Islamic Stock returns. Therefore, investors should pay attention to ROA before investing in Islamic capital market.
\end{abstract}

Keywords: Islamic stock returns, return on assets, debt to equity ratio, earnings per share 


\section{INTRODUCTION}

Many individuals invest in capital market products, such as stocks. The capital market conducts an assessment or classification of securities by applying certain criteria or standards based on Fatwa of National Sharia Council and the Capital Market Institution Supervisory Agency (Bapepam-LK)

According to Bapepam-LK Decree Number II K.1, the implementation of sharia principles is distinguished based on the object and process or method of managing its business. The issuers must clearly state that business statutes do not conflict with sharia principles. This means the securities traded must be in line with the sharia principles. Additionally, all securities are calculated based on entire assets or real transactions not originating from the accounts receivable. In managing its business, the issuer also does not participate in gambling, usury (riba), illicit goods (haram), and bribes (risywah).

The price of Islamic stocks is relatively stable because they are engaged in the real sector and do not rely on the speculative business. Strong fundamental factor stimulates stock prices to move up periodically. Investors determine fundamental factors regarding issuers through financial statements published in the stock exchange.

Financial statements publication provides information to the public regarding the performance of firms. According to the Signaling theory, information is a sign of the condition and prospects of the company that serves as the basis for investment decisions (Brigham \& Ehrhardt, 2005). Furthermore, publication minimizes asymmetric information between managers and owners. In case the information about the company is scanty, the company's value will be low. Conversely, low asymmetric information increases the value of the firm because it minimizes uncertainty about prospects(Sunardi, 2010).

The internal strength of a company has a significant influence on investor decision. Generally, an Investor analyzes and measures the financial structure to forecast future benefits. Fundamental analysis can be used to assess the performance of shares and ascertain the possibility of fault risk in choosing stocks potentially not listed in the stock exchange(Tryfino, 2009).

Fundamental analysis is carried out through several stages. The initial stage is to estimate the macroeconomic factors that influence firm performance. This is followed by performance evaluation based on the industry. Each industry has different financial and managerial characteristics, and therefore, sufficient comparisons can be made. The final stages assess firm performance. The fundamental analysis predicts stock prices based on past data and the relationship between variables to estimate prices(Husnan, 2001). It emphasizes the 
assumptions of the predictive nature of intrinsic value to determine stock return and risk. The prediction result is used to compare current market prices with previous data to determine the real value.

Ozlen (2014) examined the influence of fundamental factors in macroeconomic aspects on changes in stock prices. The results showed Total Assets Turnover (TATO), Debt to Equity Ratio (DER), Current Ratio (CR), Net Profit Margin (NPM), Earning per Share (EPS), and Book Value (BV) affect stock prices significantly. TATO influences the movement stock of price in the iron, steel, textile, commerce, and transportation industries. DER affects the movement of the stock price in the food, paper, iron, steel, and transportation industries. CR affects stock price changing in the transportation industry. PER influences changes in the stock price in the paper, communication, and textile industries. Lastly, BV affects the movement of the stock price in overall industries.

The food and beverage industry fulfill most consumption needs, mainly in Muslim societies, by meeting halal products. Table 1 shows the growth of fundamental factors in the industries listed by Indonesia Sharia Stock Index (ISSI) in 2015-2019.

Table 1: The Growth of Food and Beverage Industry Listed by ISSI 2015-2019

\begin{tabular}{|c|c|c|c|c|c|c|c|c|c|c|}
\hline \multirow[t]{2}{*}{ Factors } & \multirow[t]{2}{*}{ Year } & \multicolumn{9}{|c|}{ Code } \\
\hline & & INDF & MYOR & SKBM & ICBP & SKLT & STTP & ULTJ & CEKA & ROTI \\
\hline \multirow{5}{*}{$\begin{array}{l}\text { ROA } \\
(\%)\end{array}$} & 2015 & 4,04 & 2,41 & 5,25 & 11,01 & 5,32 & 9,67 & 14,78 & 7,17 & 10 \\
\hline & 2016 & 6,41 & 2,21 & 2,25 & 12,56 & 3,63 & 7,45 & 16,74 & 17,51 & 9,58 \\
\hline & 2017 & 4,89 & 1,41 & 0,24 & 9,84 & 2,7 & 7,18 & 13,28 & 5,73 & 3,08 \\
\hline & 2018 & 4,31 & 6,41 & 0,69 & 13,31 & 1,88 & 7,58 & 10,97 & 3,51 & 0,9 \\
\hline & 2019 & 5,10 & 6,20 & 5,37 & 13,01 & 2,75 & 13,64 & 12,74 & 10,5 & 2,3 \\
\hline \multirow{5}{*}{$\begin{array}{l}\text { DER } \\
(\mathrm{X})\end{array}$} & 2015 & 1,13 & 1,18 & 1,22 & 0,62 & 1,48 & 0,9 & 0,27 & 1,32 & 1,28 \\
\hline & 2016 & 0,87 & 1,07 & 1,72 & 0,56 & 0,92 & 1 & 0,21 & 0,61 & 1,02 \\
\hline & 2017 & 0,92 & 0,68 & 0,52 & 0,56 & 0,96 & 0,73 & 0,18 & 0,5 & 1,03 \\
\hline & 2018 & 0,93 & 1,05 & 0,7 & 0,51 & 1,2 & 0,59 & 0,16 & 0,19 & 0,5 \\
\hline & 2019 & 0,89 & 1,01 & 0,71 & 0,45 & 1,21 & 0,36 & 0,17 & 0,18 & 0,51 \\
\hline \multirow{5}{*}{$\begin{array}{l}\text { EPS } \\
\text { (IDR) }\end{array}$} & 2015 & 338,02 & 1364,15 & 44,48 & 514,62 & 29,55 & 141,78 & 179,71 & 358,15 & 53,45 \\
\hline & 2016 & 472,02 & 60,6 & 30,43 & 308,73 & 29,88 & 133,18 & 243,17 & 419,66 & 55,31 \\
\hline & 2017 & 337,29 & 41,5 & 2,25 & 260,82 & 23,72 & 127,25 & 55,46 & 126,28 & 19,23 \\
\hline & 2018 & 135 & 49 & 7,13 & 392 & 20,39 & 152,4 & 53 & 60 & 6,46 \\
\hline & 2019 & 154 & 49 & 0,55 & 432 & 31,82 & 287,94 & 70 & 220 & 16,61 \\
\hline \multirow{5}{*}{$\begin{array}{l}\text { RETURN } \\
(\%)\end{array}$} & 2015 & -23 & 46 & -3 & 3 & 23 & 5 & 6 & -10 & -9 \\
\hline & 2016 & 53 & 35 & -32 & 27 & -17 & 6 & 16 & 100 & 26 \\
\hline & 2017 & -4 & 23 & 12 & 4 & 257 & 37 & 13 & -5 & -20 \\
\hline & 2018 & -3 & 29 & -3 & 17 & 36 & -13 & 4 & 6 & -5 \\
\hline & 2019 & 7 & -21 & -35 & 8 & 0 & 17 & 11 & 31 & 1 \\
\hline
\end{tabular}

The table shows nine issuers consistently registered in ISSI during the 2015-2019 period. The highest stock returns were $257 \%$, and the lowest was $-23 \%$. Overall, ROA is positive, indicating the issuer always recorded a profit for the periods. DER varies between issuers, and the average proportion of debt is consistently higher than its capital, while PER is sufficient throughout. 
Previous research on the influence of fundamental factors on stock returns had varied findings. For instance, Zadeh, Zartab, Fatemi, and Radmanesha (2013) stated that stock returns are explained by 9 factors, including the debt to equity ratio. Utami (2014) showed evidence that economic value-added return on equity, while return on assets does not affect stock returns. According to Wijaya (2015), return on assets, dividend yield, earnings yield, and book to market value affect stock returns. In contrast, the debt to equity ratio does not affect stock returns. Anugrah and Syaichu (2017) established that the debt to equity ratio affects stock returns. Supriantikasari and Utami (2019) stated that exchange rates affect stock returns, while return on assets, current ratio, debt to equity ratio, and earning per share have no impact on it. Similarly, Jazai, Subiyantoro, and Harmono (2019) established that earning per share affects stock returns. Anjani and Syarif (2019) showed that the debt to equity ratio affects stock returns.

This study examines the influence of issuers' fundamental factors on the rate of return of Islamic stocks in Indonesia during 2015-2019. The shares are selected from the Indonesia Sharia Stock Index (ISSI) as a composite index of Islamic stocks registered in Indonesia Stock Exchange (IDX). The index is convenient for an investor to search stock price movements and determine market conditions, which can be bullish or bearish. The index serves as a guide to determine market trends and issuers' performance, forming the basis for portfolio selection (Darmadji \& Fakhruddin, 2011).

\section{Islamic Stock Returns}

The concept of return provides investors with a convenient way of expressing financial performance of investments (Brigham, Gapenski, \& Daves 1998). Spending money today means more earnings in the future, which is the essence of investing. The investment is made and results in cash inflow in several years. A realized return is useful as a basis for determining expected return in the future (Hartono, 2016.). Return in operational of Islamic capital market should focus on avoiding riba, gharar, maysir, and exploitation.

\section{Return on Assets}

Return on Assets (ROA) is an indicator of how efficient a company utilizes its assets. Profitability can be determined using ROA, which is based on the company's ability to generate profits from the assets invested. High ROA shows the effectiveness of the company in utilizing its assets to generate net income. According to signalling theory, information about ROA is a good sign for investors(Ruslim \& Michael, 2019).

\section{Debt to Equity Ratio}

Debt to Equity Ratio (DER) is a comparison between the total of liabilities to the ownership of shareholders(Van Horn \& Wachowicz Jr, 2009). In order to fulfil firm obligations, the owner should consider the capital invested. In case the ratio of debt to equity is low, the 
possibility to encounter financial problems is smaller, which increases the attractiveness for investors to buy the shares. This means the maximum total debt to total equity is bag to bag in which shareholders guarantee their capital to pay the debt (Rahardjo, 2009).

Debt indicates the conditions of a firm, which can be good or bad. Several factors are often considered when taking debt, including interest rates, operating expenses, and provision cost. Debt can drive the company's ability to expand the business and increase profit(Sinaga, 2010).

\section{Earning Per Share}

Earnings per Share (EPS) is also an indicator of firm performance and shows the amount of profit that can be received from each share owned by shareholders (Fahmi, 2015). This is a nominal value derived from profits generated by the company on each share. Higher EPS is a good signal for investors and shows that the company is performing well.

The net profit compared to the outstanding common stocks for a year, determines the amount of EPS. The calculation uses the basis of the year-end, mid-year, or quarterly audited financial statements. In case there are preferred stocks, net income is deducted first with a dividend for the share. Where net income is high, EPS can be high and profitable for investors. Conversely, small profit means EPS is small and not profitable for investors.

\section{The Influence of ROA on Islamic Stock Return}

Prospective companies prioritize internal and external sources of capital rather than selling shares to fulfil additional capital requirements. Profitability can be used to improve the firm value and bring in external capital. Information about firm profitability is a signal for the market.

Previous studies examined the significant effect of ROA on stock returns (Sutriani, 2014; Gunadi \& Kesuma, 2015; Putra \& Kindangen, 2016). ROA is the proportion of tax to total assets. The higher the ROA, the better the company produces profits from the assets invested in it. A higher ROA increases the chance of demand on the firm stocks. In case demand is high, the stock price tends to rise, increasing the returns. Therefore, the hypothesis for the study is formulated as:

H1: ROA positively influences Islamic Stocks Return

\section{The Influence of DER to Islamic Stock Return}

The composition of debt to equity determines Islamic shares. A share is declared as Islamic stock in case the composition of debt and equity does not exceed $45 \%$ of total assets. Therefore, the maximum debt is $45 \%$, and the capital is $55 \%$. With this structure, a company is expected to utilize more capital participation schemes to avoid corporate financial pressure. Also, the proportion of interest-based and non-halal to business income and is not more than $10 \%$. 
Studies indicate that the debt to equity ratio hurts the stock return (Arista \& Astohar, 2012; Thrisye \& Simu, 2013; Ismayanti \& Yusniar, 2014). The high corporate debt raises investor concerns about the magnitude of the risk. This is because most income, and therefore net income available to shareholders will be smaller. High debt reduces conflict between owner and manager. However, it also increases the risk of firm liquidity and returns. Therefore, the second hypothesis for the study is:

\section{H2: DER negatively influences Islamic Stock Return}

\section{The Influence of EPS on Islamic Stock Return}

Earnings per share have a positive effect on stock returns (Gunadi \& Kesuma, 2015; Widasari \& Faridoh, 2017; Ayem \& Astuti, 2019). An increase of EPS is a good illustration of firm performance in yielding profit. In case the income per share is low, the demand for the shares decreases, lowering the share price. In case the stock price falls, the rate of return will be negative. Therefore, the third hypothesis for the study is:

\section{H3: EPS positively influences Islamic Stock Return}

\section{METHOD}

This study uses a quantitative approach with data from financial statement documents published on the official website of the IDX. The study was conducted on Food and Beverage companies registered in ISSI. It used eleven companies selected using purposive sampling. The issuers were consistently registered in ISSI during 2015-2019, published financial reports continuously in that observed period, and had complete data with no negative EPS.

Based on this criteria, nine companies were selected, including Indofood Sukses Makmur Tbk (INDF), Mayora Indah Tbk (MYOR), Sekar Bumi Tbk (SKMB), Indofood CBP Sukses Makmur Tbk (ICBP), Sekar Laut Tbk (SKLT), Siantar Top Tbk (STTP), Wilmar Cahaya Indonesia Tbk (CEKA), Ultra Jaya Milk Industry and Trading Tbk (ULTJ), and Nippon Indosari Corpindo Tbk (ROTI).

The variables were determined using financial ratios. The dependent variable was the Islamic rate of return, while independent variables included ROA, DER, and EPS. Islamic rate of return is the excess of the closing price of the current year $(\mathrm{t})$ on the closing price of the previous year ( $\mathrm{t}-1)$ divided by the closing price of the previous year. ROA is the ratio of net income to total assets of the company. DER is the ratio of the total debt to equity, and EPS is the proportion of net income to the number of outstanding shares. Islamic return and ROA are presented in percentage (\%), DER in times (x), and EPS in Indonesia Rupiah(IDR). 
The equation of pooled data regression is:

$\operatorname{Ret}_{\mathrm{it}}=\alpha+\beta_{1} \mathrm{ROA}_{\mathrm{it}}+\beta_{2} \mathrm{DER}_{\mathrm{it}}+\beta_{3} \mathrm{EPS}_{\mathrm{it}}+\mathrm{e}_{\mathrm{it}}$

Where: Ret is Islamic Stock Return; ROA is Return on Assets; DER is Debt to Equity Ratio; EPS is Earnings per Shares; $\alpha$ is constant; $\beta$ is coefficient, and e is the error term

The pooled data is processed to eliminate data bias between periods. Pooled data is integrated from the cross-section and time-series data. The stages in this test include estimation of pooled data including regression models, selection of pooled data regression models, classic assumption tests, and hypothesis test. The test in pooled data regression models are based on Common, Fixed, and Random Effect models (Winarno, 2009). The next step involves Hausman, Chow, and Lagrangian Multiplier tests. The Hausman test is conducted to select the best model between Fixed Effect (FE) and Random Effect (RE), while Lagrangian Multiplier (LM) test examines whether RE is better than Ordinary Least Square (OLS) test. The classic assumption test examines the degree of deviation on serial correlations, normality, linearity, heteroscedasticity, and multicollinearity.

\section{RESULTS AND DISCUSSION}

\section{Chow Test Result}

Table 2. Chow Test

\begin{tabular}{|c|c|c|c|}
\hline Effect Test & Statistic & d.f. & Prob. \\
\hline Cross -section F & 1.518324 & $(8.33)$ & 0.1887 \\
\hline $\begin{array}{l}\text { Cross -section Chi } \\
\text { square }\end{array}$ & 14.103327 & 8 & 0.0791 \\
\hline
\end{tabular}

The Chow test serves to choose the estimation model between the Common Effect (CE) and the Fixed Effect (FE). In case the probability value (p-value) of chi-square crosssection is less than 0.05 , the FE is better than the CE estimation model. In contrast, in case the probability value is greater than 0.05 , the CE is better than the FE model.

Based on case table 2, the result of the eChow test shows that the statistical distribution of cross-section chi-square is 14.103327 with a significance level at 0.0791 . Therefore, in case p-value is greater than 0.05 , the CE is better than the FE estimation model.

\section{Hausman Test Result}

Table 3. Hausman Test

\begin{tabular}{lrrr}
\hline Test Summary & Chi -Sq. Statistic & Chi - Sq. d.f. & Prob. \\
\hline Cross - section & 3.573865 & 3 & 0.3113 \\
Random & & & \\
\hline
\end{tabular}


The Hausman test is used to determine the best estimation model between FE and RE. In case the random cross-section (SCR) is significant at a probability of less than $0.05, \mathrm{FE}$ should be used. However, in case the SCR value is not significant, RE is better that FE model.

Table 3 presents the Hausman test result, where the SCR value is 3.573865 with a significant level at 0.311 . The significant value is greater than 0.05 , and therefore the RE model is better than the FE. Since the Chow and the Hausman tests produce different estimation models, it necessary to conduct the LM test.

\section{Lagrangian Multiplier Test Result}

Table 4. Lagrangian Multiplier Test

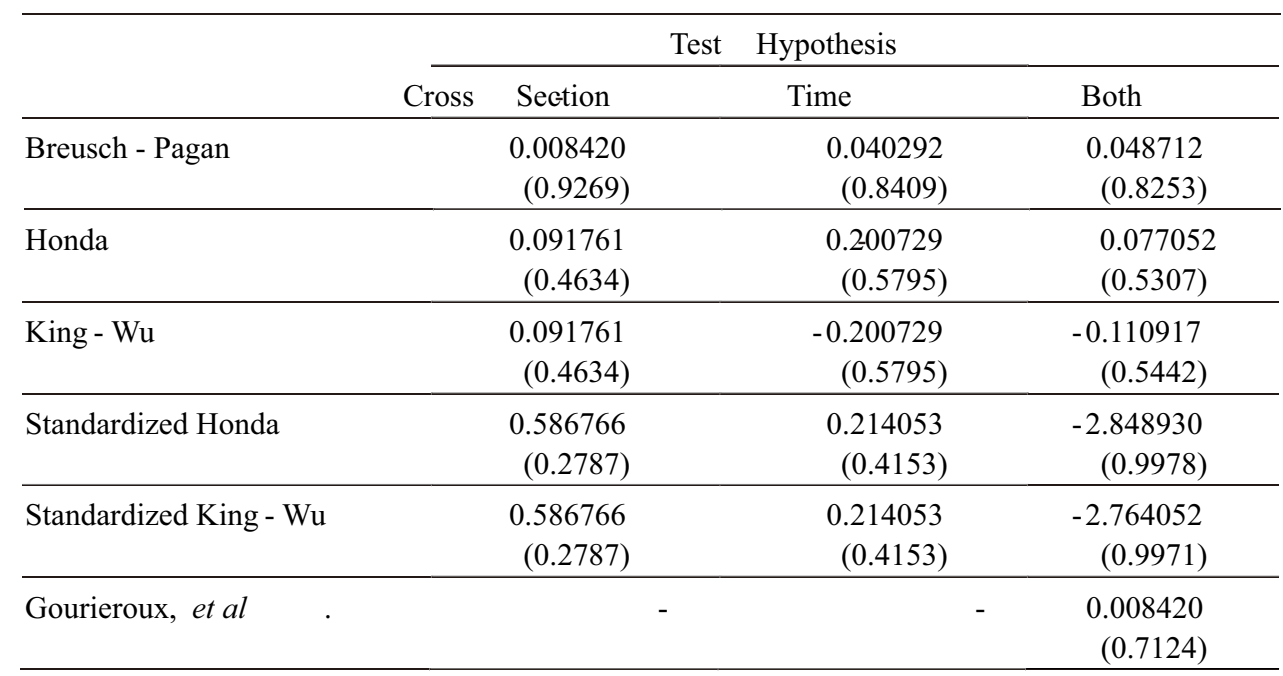

The LM test determines whether it is appropriate to use the random model. The LM statistical value is calculated based on the number of observations, periods, and the OLS residual value or merely looking at the value of the Breusch-Pagan Cross Section (BPCR). In case the probability value of BPCR is less than 0.05 , it is appropriate to choose the random model. However, in case it is greater than 0.05 , the common model is appropriate.

Based on the LM test in table 4, the Breusch-Pagan value is 0.008420 in the significant level 0.9269 . Since this value is greater than 0.05 , the hypothesis stating that random model is better than the common model is rejected.

\section{Classic Assumption Test Result}

The classic assumption test determines the presence of bias in a linear approach. This test includes the autocorrelation, normality, multicollinearity, and heteroscedasticity. 
Table 5. Summary of Classic Assumption Test

\begin{tabular}{lr}
\hline Test & Value \\
\hline Durbin Watson & 1.983828 \\
\hline Jarque -Bera & 4.322383 \\
& $(0.115188)$ \\
\hline Centred VIF & \\
ROA & 1.683361 \\
DER & 1.130800 \\
EPS & 1.557663 \\
\hline Obs*R -squared & 2.384837 \\
& $(0.4965)$ \\
\hline
\end{tabular}

Autocorrelation test is used to determine the correlation between current data and the previous data. In this study, the Durbin Watson value is 1.983828 , which is greater than the DU value. Therefore, there is no autocorrelation problem in this data.

Normality test shows whether the data is normally distributed based on the JarqueBera (JB) value. In case the JB has a significant value of less than 0.05 , the data is not normally distributed. However, suppose it is greater than 0.05 , the data is normally distributed. Based on the normality test, the JB is 4.322383 with a probability value of 0.115188 . Therefore, the data is normally distributed with the probability value greater than 0.05

The purpose of multicollinearity test is to determine whether there is a linear relationship between independent variables. A good liner regression model requires the absence of multicollinearity. In case the Centered VIF is smaller than 10, there is no multicollinearity. In this study, the Centered VIF value of all three independent variables is less than 10 . Therefore, there is no multicollinearity in this model.

The heteroscedasticity measures data homogeneity through Glejser test. In the probability of Obs*R-squared is greater than 0.05 , there is no heteroscedasticity. The result of the test shows that Obs*R-squared is 2.384837 with the probability value at 0.9465 , which is greater than 0.05 . Therefore, there is no heteroscedasticity problem.

\section{Final Model Selection}

The selection of an estimation model is conducted to determine the most appropriate model for hypothesis testing. The following table shows the test result based on all three estimation models, specifically: Common Effect, Fixed Effect, and Random effect. 
Table 6. Summary of Pooled Data Regression Model

\begin{tabular}{crrr}
\hline Variables & Common Effect & Fixed Effect & Random Effect \\
\hline C & $-0,121237$ & 0,159389 & 0,069326 \\
t-Stat & $(-1,419872)$ & $(0,665343)$ & $(0,315293)$ \\
prob. & $(0,1632)$ & $(0,5105)$ & $(0,7541)$ \\
\hline ROA & 1,708857 & 2,919934 & 1,177417 \\
t-Stat & $(2,181944)$ & $(1,325218)$ & $(0,713920)$ \\
prob. & $(0,0075)$ & $(0,1942)$ & $(0,4793)$ \\
\hline DER & 0,026048 & $-0,355776$ & $-0,052857$ \\
t-Stat & $(0,348505)$ & $(-1,399040)$ & $(-0,271531)$ \\
prob. & $(0,7292)$ & $(0,1711)$ & $(0,7873)$ \\
\hline EPS & 0,00009 & 0,000114 & 0,000114 \\
t-Stat & $(0,738870)$ & $(0,278026)$ & $(0,311095)$ \\
Prob. & $(0,4642)$ & $(0,7827)$ & $(0,7573)$ \\
\hline R-Squared & 0.279407 & 0.287993 & 0.035160 \\
F-Statistic & 5.299203 & 0.316817 & 0.498025 \\
\hline
\end{tabular}

Source: Data Processing with Eviews

Table 6 shows the results of testing the estimation model with Common Effect (CE), Fixed Effect (FE), and Random Effect (RE). Based on a series of goodness tests, the model that can be used as the basis for analysis is CE. The result shows that ROA has a coefficient of 1.708857 (t-stat=2.181944; prob=0.0075). The ROA probability value is less than 0.05 . Therefore, ROA has a significant effect on Islamic stock's return. The DER coefficient is 0.026048 (t-stat=0.348505; prob=0.7292). DER probability value is greater than 0.05 , and therefore it does not affect the Islamic rate of return. Furthermore, the EPS coefficient is 0.00009 (t-stat $=0.738870 ;$ prob $=0.4642$ ), meaning that it does not affect Islamic stock return.

This finding supports Aldiena and Hakim (2019), which established that ROA partially has a significant effect on stock returns of companies listed in the Jakarta Islamic Index (JII). The finding is also in line with Devi and Artini (2019), which stated that ROA has a positive effect on stock returns of property and real estate companies listed in the Indonesia Stock Exchange.

According to the signalling theory, the profitable company indirectly provides better information about the market. Profitability indicators are part of public communication, and it is different in a less profitable company. When earning is high, the prospect and opportunity for the increasing dividend are positive.

Return results from investment activities for shareholders when they sell their shares. In general, it consists of expected and actual returns. Investors put their funds expecting return with or without ignoring risks. In other words, a return is a reward for bearing risks (Tandelilin, 2001).

Shareholders expect to gain benefits in the form of dividend and capital gain due to the volatility of stock prices. Fundamental analysis provides the appraisal method for making 
investment decisions. This model focuses on the internal performance that might affect future returns. The indicators are determined using financial ratios from several aspects, such as liquidity, solvency, efficiency, profitability, or market value. Information about profitability is required by an investor to determine the profile, prospect, and performance of a company.

Investors in Islamic stock market empirically consider the stability of firm return to maximize profit. Islamic stock return is influenced by ROA, which means that in case a company has sufficient and stable profit, the stock price shows positive trends. However, DER and EPS do not affect Islamic stock returns. Stock price movements are not driven by capital structure and the amount of income on each share.

Sharia-based securities investment is a critical part of capital market growth in Indonesia. People choose to allocate funds in the Islamic capital market instrument driven by spirituality. Moreover, some investors choose Islamic instruments based on their profitability. They make decisions based on technical factors using price trends through the information centre provided by security companies and virtual market. A summary of the hypothesis test is shown in Table 7 below.

Table 7. Hypothesis Test Summary

\begin{tabular}{llll}
\hline Variables & Direction & Result & Decision \\
\hline ROA & Positive $(+)$ & Significant & Accepted \\
\hline DER & Positive $(+)$ & Not Significant & Rejected \\
\hline EPS & Positive $(+)$ & Not Significant & Rejected \\
\hline
\end{tabular}

\section{CONCLUSION}

This study shows that ROA determines Islamic stock returns. Profitability attracts investors to make critical decisions. An increase in stock price pushed returns in a positive direction. Forceful fundamentals help increases value and share prices of firms in the long run.

DER does not affect the Islamic rate of returns. The composition of debt and capital does not affect investors' decisions to buy shares. However, they are likely to reconsider their decisions, depending on the amount of debt at a stage of liquidity. The direction of the DER relationship on stock returns is positive, showing that investors do not consider the debt structure of the firm.

The hypothesis test shows that EPS also does not affect Islamic stock returns. The common effect model shows that the direction is positive but not significant. Investors do not consider these factors in the investment decision. The elements that determine EPS include income level, cost efficiency, debt, and tax rate. In case the amount of dividend is high, EPS is greater. 
This research can be used as a reference for making investment decisions. Fundamental factors represent the strength, weakness, and opportunity of the company. The ability to produce profit shows the commitment of the board of directors to increase shareholders' wealth. Although DER does not affect Islamic stock return, it is necessary to pay attention to the desire to invest in sharia instruments.

This study has two main limitations, including: (1) a few numbers of the sample in the Islamic stock market, especially in consumption industry and (2) a limited number of fundamental variables. This study would be more appropriate if used for parties who desire to invest in the food and beverage sector. In future studies, the number of samples and variables should be increased. Research also can be conducted in different Islamic indexes and industries.

\section{BIBLIOGRAPHY}

Aldiena, E., \& Hakim, M. H. (2019). The Impact of Companies' Internal Factors on the Performance of Their Stock Returns. Journal of Islamic Economic Laws, 2(1), 120-149. DOI: https://doi.org/10.23917/jisel.v2i1.7708

Anjani, T., \& Syarif, A. D. (2019). The Effect of Fundamental Analysis on Stock Returns using Data Panels; Evidence Pharmaceutical Companies listed on IDX. International Journal of Innovative Science and Research Technology, 4(7), 500-505.

Anugrah, A., \& Syaichu, M. (2017). Analisis Pengaruh Return on equity, Debt to Equity Ratio, Current Ratio, dan Price to Book Value terhadap Return Saham Syariah (Studi Kasus pada Perusahaan yang Terdaftar Dalam Jakarta Islamic Index Periode 2011 - 2015 ). Diponegoro Journal of Management, 6(1), 1-12.

Arista, D., \& Astohar, A. (2012). Analisis Faktor -Faktor yang Mempengaruhi Return Saham (Kasus pada Perusahaan Manufaktur yang Go Public di BEI periode tahun 2005 - 2009) Jurnal Ilmu Manajemen dan Akuntansi Terapan (JIMAT), 3(1), 1-15.

Ayem, S., \& Astuti, B. (2019). Pengaruh Earning Per Share (EPS), Leverage,Ukuran Perusahaan, Dan Tax Planning terhadap Return Saham Perusahaan (Studi Kasus Pada Perusahaan Sub Sektor Perbankan yang Terdaftar di Bursa Efek Indonesia Periode Waktu 2013 - 2017 Jurnal Akuntansi Dewantara, 3(2), 89 - 105.

Brigham, E. F., \& Ehrhardt, M. C. (2005).Financial Management: Theory and Practice. SouthWester $\mathrm{n}$ : Thomson.

Brigham, E. F., Gapenski, L. C., \& Daves, P. R. (1998).Intermediate Financial Management Sixth Edition. Forth Worth : Dryden Press.

Darmadji, T., \& Fakhruddin, H. M. (2011). Pasar Modal di Indonesia, Edisi 3. Jakarta:Salemba. Devi, N. N. S. J. P, \& Artini, L. G. S. (2019). Pengaruh ROE, DER, PER, dan Nilai Tukar Terhadap Return Saham. E-Jurnal Manajemen, 8(7), 4183-4212. DOI: https://doi.org/10.24843/ EJMUNUD.2019.v08.107.p07 
Fahmi, I. (2015). Pengantar Teori Portofolio dan Analisis Investasi. Bandung: Alfabeta.

Gunadi, G. G., \& Kesuma, K. W. (2015). Pengaruh ROA, DER, EPS terhadap Return Saham Perusahaan Food and Beverage BEI. E-Jurnal Manajemen, 4(6), 1636-1647.

Hartono, J. (2016.). Teori Portofolio dan Analisis Investasi: Edisi Kesebelas. Yogyakarta: BPFE.

Van Horn, J. C., \& Wachowicz Jr, J. M. (2009). Fundamental of Financial Management 13th Edition. New Jersey: Prentice Hall.

Husnan, S. (2001). Teori Portofolio dan Analisis Sekuritas. Yogyakarta: YKPN.

Ismayanti, D., \& Yusniar, M. W. (2014). Pengaruh Faktor Fundamental dan Risiko (Beta) terhadap Return Saham Pada Perusahaan yang Termasuk dalam Indeks LQ 45. Jurnal Wawasan Manajemen, 2(1), 1-20. DOI: http://dx.doi.org/10.20527/jwm.v2i1.30.

Jazai, R., Subiyantoro, E., \& Harmono, H. (2019). Pengaruh EPS, ROI dan EVA terhadap Return Saham Perusahaan Otomotif di Bursa Efek Indonesia (BEI). Jurnal Sosial Humaniora dan Pendidikan, 3(1), 47-54. DOI: https://doi.org/10.32487/ jshp.v3i1. 539.

Ozlen, S. (2014). The Effect of Company Fundamentals on Stock Values. European Researcher: International Multidisciplinary Journal, 71(3), 595-602.

Putra, F. E., \& Kindangen, P. (2016). Pengaruh Return on Asset (ROA), Net Profit Margin (NPM), dan Earning Per Share (EPS) Terhadap Return Saham Perusahaan Makanan dan Minuman yang Terdaftar di Bursa Efek Indonesia (Periode 2010-2014). Emba: Jurnal Riset Ekonomi, Manajemen, Bisnis dan Akuntansi, 4(3), 235-245. DOI: https://doi.org/10.35794/emba.v4i3.13717.

Rahardjo, B. (2009). Jeli Investasi Saham Ala Warren Buffet. Yogyakarta: Andi.

Ruslim, H., \& Michael. (2019). The Effect of Financial Ratio on Company Value with Inflation as a Moderation Variable. Jurnal Akuntansi, XXIII(1), 34-46. DOI: http://dx.doi.org/ 10.24912/ja.v23i1.458

Sinaga, B. (2010). Kitab Suci Pemain Saham. Jakarta: Gerrmedia Komik.

Sunardi, H. (2010). Pengaruh Penilaian Kinerja dengan ROI dan EVA terhadap Return Saham pada Perusahaan yang Tergabung dalam Indeks LQ 45 di Bursa Efek Indonesia. Jurnal Akuntansi, 2(1), 70-92.

Supriantikasari, N., \& Utami, E. S. (2019). Pengaruh Return on Assets, Debt to Equity Ratio, Current Ratio, Earning per Share dan Nilai Tukar terhadap Return Saham (Studi Kasus Pada Perusahaan Go Public Sektor Barang Konsumsi yang Listing di Bursa Efek Indonesia Periode 2015-2017). Jurnal Riset Akuntansi Mercu Buana, 5(1), 49-66. DOI: https://doi.org/10.26486/jramb.v5i1.814.

Sutriani, A. (2014). Pengaruh Profitabilitas, Leverage, dan Likuiditas terhadap Return Saham dengan Nilai Tukar Sebagai Variabel Moderasi Pada Saham LQ-45. Journal of Business and Banking, 4(1), 67-80. DOI: http://dx.doi.org/10.14414/jbb.v4i1.294.

Tandelilin, E. (2001). Analisis Investasi dan Manajemen Portofolio. Yogyakarta: BPFE.

Thrisye, R. Y., \& Simu, N. (2013). Analisis Pengaruh Rasio Keuangan terhadap Return Saham BUMN Sektor Pertambangan Periode 2007-2010. Jurnal Ilmiah Akuntansi dan Bisnis, $8(2), 75-81$. 
Tryfino. (2009). Cara Cerdas Berinvestasi Saham. Jakarta: TransMedia Pustaka.

Utami, W. B. (2014). Analisis Pengaruh EVA, ROA dan ROE terhadap Return Saham Pada Perusahaan Manufaktur di Bursa Efek Jakarta Tahun 2006-2008. Jurnal Akuntansi dan Pajak, 14(2), 1-19. DOI: http://dx.doi.org/10.29040/jap.v14i02.72.

Widasari, E., \& Faridoh, V. (2017). Pengaruh Return on Investment (ROI), Return on Equity (ROE), Earning Per Share (EPS) dan Economic Value Added (EVA) terhadap Return Saham. The Asia Pasific Journal of Management Studies, 4(2), 55-60.

Wijaya, J. A. (2015). The Effect of Financial Ratios toward Stock Returns among Indonesian Manufacturing Companies. iBuss Management, 3(2), 261-271.

Winarno, W. W. (2009). Analisis Ekonometrika dan Statistika Dengan EViews (Edisi 4). Yogyakarta: UPP STIM YKPN.

Zadeh, A. K., Zartab, S., Fatemi, S. F., \& Radmanesh, R. (2013). Fundamentals and Stock Return in Pharmaceutical Companies: A Panel Data Model of Iranian Industry. Iranian Journal of Pharmaceutical Sciences, 9(1), 55-60. 